\title{
Aging-associated changes in L-type calcium channels in the left atria of dogs
}

\author{
TIAN-YI GAN ${ }^{1 *}$, WEIWEI QIAO ${ }^{2,3^{*}}$, GUO-JUN XU $^{1}$, XIAN-HUI ZHOU ${ }^{1}$, BAO-PENG TANG $^{1}$, \\ JIAN-GUO SONG ${ }^{1}$, YAO-DONG LI ${ }^{1}$, JIAN ZHANG ${ }^{1}$, FA-PENG LI $^{1}$, TING MAO ${ }^{1}$ and TAO JIANG ${ }^{1}$ \\ ${ }^{1}$ Department of Cardiology, The First Affiliated Hospital, Xinjiang Medical University, Urumqi, Xinjiang 830011; \\ ${ }^{2}$ The Key Laboratory of Cardiovascular Remodeling and Function Research, Chinese Ministry of Education \\ and Chinese Ministry of Public Health, Shandong University, Qilu Hospital, Jinan, Shandong 250012; \\ ${ }^{3}$ Department of Cardiology, Yantaishan Hospital, Yantai, Shandong 264001, P.R. China
}

Received March 29, 2013; Accepted July 1, 2013

DOI: $10.3892 /$ etm.2013.1266

\begin{abstract}
Action potential (AP) contours vary considerably between the fibers of normal adult and aged left atria. The underlying ionic and molecular mechanisms that mediate these differences remain unknown. The aim of the present study was to investigate whether the L-type calcium current $\left(\mathrm{I}_{\mathrm{Ca} . \mathrm{L}}\right)$ and the L-type $\mathrm{Ca}^{2+}$ channel of the left atria may be altered with age to contribute to atrial fibrillation (AF). Two groups of mongrel dogs (normal adults, 2-2.5 years old and older dogs, $>8$ years old) were used in this study. The inducibility of AF was quantitated using the cumulative window of vulnerability (WOV). A whole-cell patch-clamp was used to record APs and $\mathrm{I}_{\mathrm{Ca} . \mathrm{L}}$ in left atrial (LA) cells obtained from the two groups of dogs. Protein and mRNA expression levels of the a1C (Cav1.2) subunit of the L-type calcium channel were assessed using western blotting and quantitative PCR (qPCR), respectively. Although the resting potential, AP amplitude and did not differ with age, the plateau potential was more negative and the $\mathrm{APD}_{90}$ was longer in the aged cells compared with that in normal adult cells. Aged LA cells exhibited lower peak $\mathrm{I}_{\mathrm{Ca} . \mathrm{L}}$ current densities than normal adult LA cells $(\mathrm{P}<0.05)$. In addition, the Cav1.2 mRNA and protein expression levels in LA cells were decreased in the aged group compared with those in the normal adult group. The lower AP plateau potential and the decreased $\mathrm{I}_{\mathrm{Ca} . \mathrm{L}}$ of LA cells in aged dogs may contribute to the slow and discontinuous conduction of the left atria. Furthermore, the reduction of the expression levels of Cav1.2 with age may be the molecular mechanism that mediates the decline in $\mathrm{I}_{\mathrm{Ca.L}}$ with increasing age.
\end{abstract}

Correspondence to: Professor Bao-Peng Tang, Department of Cardiology, The First Affiliated Hospital, Xinjiang Medical University, 137 Liyushan South Road, Urumqi 830011, P.R. China E-mail: tangbpgan@163.com

*Contributed equally

Key words: atria, calcuim channel, cellular electrophysiology, aging

\section{Introduction}

Aging is known to increase the propensity for the occurrence of atrial arrhythmias, particularly atrial fibrillation (AF) $(1,2)$. AF usually occurs in conjunction with other cardiovascular diseases; however, not all patients with AF have an underlying disease (3). This suggests that age-associated changes in the atrium may be important in the development of AF (4). However, the electrophysiological changes that cause the atria of elderly individuals to be more susceptible to AF than those of younger adults remain poorly understood.

The role of the left atrium in the development of AF has previously been identified (5), and previous studies have shown that in left atrial (LA) tissue, the action potential (AP) duration (APD) is prolonged and the AP plateau becomes increasingly negative with age $(6,7)$. These alterations in the AP may provide a substrate for reentry, which facilitates the occurrence and maintenance of reentrant arrhythmias, including AF (8). The L-type $\mathrm{Ca}^{2+}$ current $\left(\mathrm{I}_{\mathrm{Ca} . \mathrm{L}}\right)$ is the major current determining the plateau level of the AP; thus, variations in $\mathrm{I}_{\mathrm{Ca} . \mathrm{L}}$ may lead to changes in the AP plateau level. Previous studies have reported that $\mathrm{I}_{\mathrm{Ca.}}$ is reduced in the right atrial (RA) cells of aged canines compared with that in cells from younger adult canines $(9,10)$. However, to the best of our knowledge, there are few published data on the effects of age on LA $\mathrm{I}_{\mathrm{Ca} . \mathrm{L}}(7)$.

The $\mathrm{I}_{\mathrm{Ca} . \mathrm{L}}$ is mediated by the L-type $\mathrm{Ca}^{2+}$ channel. The a1C (Cav1.2) subunit is considered to be the most important polypeptide of the $\mathrm{Ca}^{2+}$ channel-forming proteins, since it forms the channel pore for ion flow. However, published data concerning the effects of age on LA Cav1.2 expression levels are lacking.

In the present study, we tested the hypothesis that $\mathrm{I}_{\mathrm{Ca.L}}$ and Cav1.2 expression levels in the left atrium change with age, creating a substrate that favors the initiation of AF. This was achieved by investigating the differences in $\mathrm{I}_{\mathrm{Ca} . \mathrm{L}}$ and Cav1.2 expression in LA myocardia between adult and aged dogs.

\section{Materials and methods}

Ethics. All experiments conformed to the Guide for the Care and Use of Laboratory Animals published by the US National Institutes of Health (11). All animal studies were approved by 
the Animal Use and Care Committee of the First Teaching Hospital, Xinjiang Medical University (Urumqi, China).

Animal preparation. Seven adult (2-2.5 years old) and ten aged ( $>8$ years old) mongrels of either gender, weighing $18-26 \mathrm{~kg}$, were used in this study. The ages of the dogs were estimated by a veterinarian based on standard measures for age, including dentition, coat, eyes and musculoskeletal and conformational descriptors. All dogs were anesthetized with sodium pentobarbital $(30 \mathrm{mg} / \mathrm{kg})$ and ventilated with atmospheric air using a positive pressure respirator. Core body temperature was maintained at $36.5 \pm 1.5^{\circ} \mathrm{C}$. The dogs were subjected to twelve-lead electrocardiograms (ECGs) to confirm sinus rhythm and echocardiograms were performed to exclude structural heart disease. Subsequently, continuous recording of standard ECG leads was carried out to determine the heart rate and rhythm. Blood pressure (BP) was continuously monitored via a pressure transducer positioned in the right femoral artery.

The chest was entered via a left thoracotomy at the 4 th intercostal space. Multi-electrode catheters (Biosense-Webster, Diamond Bar, CA, USA) were secured to allow recording at the LA appendage (LAA), left superior pulmonary vein (LSPV) and left inferior pulmonary vein (LIPV). Similar electrode catheters were attached to the RA appendage (RAA), right superior pulmonary vein (RSPV) and right inferior pulmonary vein (RIPV) via a right thoracotomy at the 4th intercostal space. All traces from the electrode catheters were amplified and digitally recorded using a computer-based Lab System (GE 2000; General Electric Company, Fairfield, CT, USA). Bipolar electrograms were filtered at 30-500 Hz. ECG filter settings were $0.1-250 \mathrm{~Hz}$.

Induction of AF. Rapid atrial pacing was delivered $(1,000 \mathrm{bpm}$; $2 \mathrm{X}$ threshold; duration, $1 \mathrm{msec}$ ) at the RAA. After $30 \mathrm{~min}$, rapid atrial pacing was terminated in order to measure $\mathrm{AF}$ inducibility. Programmed stimulation at atrial myocardial sites or pulmonary vein (PV) sleeves was performed using a programmable stimulator (DF-4A; Suzhou Dongfang Electronic Instrument Factory, Suzhou, China). Programmed pacing consisted of eight consecutive stimuli (S1-S1, cycle length $=330 \mathrm{msec}$ ) followed by a premature stimulus (S1-S2) that was progressively decremented until refractoriness. Pacing was performed at $2 \mathrm{X}$ diastolic threshold $(\mathrm{TH})$ and at $4 \mathrm{X} \mathrm{TH}$. AF was defined as irregular atrial rates $(>500 \mathrm{bpm})$ associated with irregular atrioventricular conduction (lasting $>5 \mathrm{sec}$ ). The window of vulnerability (WOV) was used as a quantitative measure of AF inducibility. AF inducibility was quantitated as the longest S1-S2 minus the shortest S1-S2 that induced $\mathrm{AF}$ at each pacing $\mathrm{TH}$. The cumulative WOV was the sum of the individual WOVs.

Atrial myocyte preparation. Following intravenous (i.v.) administration of pentobarbital $(30 \mathrm{mg} / \mathrm{kg})$ and thoracotomy, the heart was rinsed in oxygenated $\mathrm{Ca}^{2+}$-free Tyrode's solution $[137 \mathrm{mmol} / 1 \mathrm{NaCl}, 5.4 \mathrm{mmol} / \mathrm{l} \mathrm{KCl}$, $1.0 \mathrm{mmol} / 1 \mathrm{MgCl}_{2}, 0.33 \mathrm{mmol} / 1 \mathrm{NaH}_{2} \mathrm{PO}_{4,}, 10 \mathrm{mmol} / \mathrm{l} \mathrm{HEPES}$ and $10 \mathrm{mmol} / 1$ glucose (adjusted to $\mathrm{pH} 7.4$ with $\mathrm{NaOH}$ )]. The aorta was cannulated and the heart was retrogradely perfused on a Langendorff apparatus (ADInstruments, Inc., New
South Wales, Australia) at $37^{\circ} \mathrm{C}$. A perfusion with $\mathrm{Ca}^{2+}$-free Tyrode's solution for $5 \mathrm{~min}$ was followed by perfusion with $\mathrm{Ca}^{2+}$-free Tyrode's solution containing $0.03 \%$ collagenase-II (Worthington Biochemical, Lakewood, NJ, USA) and 1\% BSA for $35 \mathrm{~min}$. The left atria were dissected, minced and gently triturated with a pipette in the low- $\mathrm{Ca}^{2+}$ Tyrode's solution containing $1 \% \mathrm{BSA}$ at $37^{\circ} \mathrm{C}$ for $10 \mathrm{~min}$. The cells were filtered through $200-\mu \mathrm{m}$ nylon mesh and resuspended in the Tyrode's solution, in which the $\mathrm{Ca}^{2+}$ concentration was gradually increased to $1.0 \mathrm{mmol} / \mathrm{l}$. Only cells with a rod-shaped morphology and clear cross-striation were used for subsequent experiments.

Cellular electrophysiology. LA cells were continuously superfused $(2-3 \mathrm{ml} / \mathrm{min})$ in a $1-\mathrm{ml}$ bath with normal Tyrode's solution [137 mmol/1 NaCl, $5.4 \mathrm{mmol} / 1 \mathrm{KCl}, 1.0 \mathrm{mmol} / 1$ $\mathrm{MgCl}_{2}, 1.8 \mathrm{mmol} / \mathrm{l} \mathrm{CaCl}, 0.33 \mathrm{mmol} / 1 \mathrm{NaH}_{2} \mathrm{PO}_{4}, 10 \mathrm{mmol} / \mathrm{l}$ HEPES and $10 \mathrm{mmol} / 1$ glucose (adjusted to $\mathrm{pH} 7.4$ with $\mathrm{NaOH})]$. The solution was bubbled with $100 \% \mathrm{O}_{2}$. Membrane currents and APs were recorded using whole-cell patch-clamp techniques with an EPC 10 Double amplifier and Patchmaster software (HEKA Elektronik Dr. Schulze GmbH, Lambrecht/ Pfalz, Germany). Patch pipette resistances ranged from 2.0-3.0 M $\Omega$ when filled with an internal solution. APs were recorded in current-clamp mode. The solution for AP recordings contained $137 \mathrm{mmol} / \mathrm{l} \mathrm{NaCl}, 5.4 \mathrm{mmol} / \mathrm{l} \mathrm{KCl}$, $1.0 \mathrm{mmol} / 1 \mathrm{MgCl}_{2}, 1.8 \mathrm{mmol} / 1 \mathrm{CaCl}_{2}, 10 \mathrm{mmol} / 1 \mathrm{HEPES}$ and $20 \mathrm{mmol} / 1$ glucose (adjusted to $\mathrm{pH} 7.4$ with $\mathrm{KOH}$ ). The internal electrode solution for AP recordings contained $140 \mathrm{mmol} / 1 \mathrm{KCl}, 2.0 \mathrm{mmol} / \mathrm{l} \mathrm{MgCl}{ }_{2}, 2.0 \mathrm{mmol} / 1$ egtazic acid, $5.0 \mathrm{mmol} / \mathrm{l} \mathrm{HEPES}, 5 \mathrm{mmol} / \mathrm{l} \mathrm{EGTA}$ and $4.0 \mathrm{mmol} / \mathrm{Na}_{2}$ ATP (adjusted to $\mathrm{pH} 7.4$ with $\mathrm{KOH}$ ). The $\mathrm{Ca}^{2+}$ currents were recorded in voltage-clamp mode. The external solution for $\mathrm{I}_{\mathrm{Ca}-\mathrm{L}}$ recording contained $137 \mathrm{mmol} / \mathrm{l}$ choline- $\mathrm{Cl}, 2.0 \mathrm{mmol} / \mathrm{l}$ $\mathrm{CaCl}_{2}, 1.0 \mathrm{mmol} / 1 \mathrm{MgCl}_{2}, 5 \mathrm{mmol} / 1 \mathrm{HEPES}, 10 \mathrm{mmol} / \mathrm{l}$ glucose, $4.6 \mathrm{mmol} / \mathrm{l} \mathrm{CsCl}, 10 \mathrm{mmol} / \mathrm{l} \mathrm{TEA}-\mathrm{Cl}$ and $5 \mathrm{mmol} / \mathrm{l}$ 4-aminopyridine (4-AP) (adjusted to $\mathrm{pH} 7.30$ with $\mathrm{CsOH}$ ). The internal solution for $\mathrm{I}_{\text {Ca.L }}$ recording contained $120 \mathrm{mmol} / \mathrm{l}$ $\mathrm{CsCl}, 1.0 \mathrm{mmol} / \mathrm{l} \mathrm{MgCl}_{2}, 5.0 \mathrm{mmol} / 1 \mathrm{MgATP}, 10 \mathrm{mmol} / 1$ BAPTA, $10 \mathrm{mmol} / \mathrm{l} \mathrm{HEPES}$ and $10 \mathrm{mmol} / \mathrm{l} \mathrm{TEA}-\mathrm{Cl}$ (adjusted to $\mathrm{pH} 7.3$ with $\mathrm{CsOH}$ ). Data acquisition was initiated $10 \mathrm{~min}$ after membrane rupture. $\mathrm{I}_{\mathrm{Ca.L}}$ magnitudes were normalized by the membrane capacitance $(\mathrm{pF})$ of each cell and expressed as current density $(\mathrm{pA} / \mathrm{pF})$. Recordings were filtered using lowpass $(2 \mathrm{~Hz})$ and high-pass $(30 \mathrm{~Hz})$ filters.

Detection of Cavl.2 gene expression. Total RNA was extracted from LAA samples using TRIzol (Gibco-BRL, Carlsbad, CA, USA). Total RNA was reverse transcribed using ReverTra Ace (Toyobo Biotech Co.,Ltd., Osaka, Japan). The expression levels of target genes were measured by quantitative PCR (qPCR) using Sybr-Green qPCR Master Mix (Bio-Rad, Hercules, CA, USA). In each assay, $\beta$-actin (used as an endogenous control) and Cav1.2 genes from the same samples were amplified in triplicate in separate tubes. The mRNA levels of Cav1.2 were determined using the relative standard curve method, normalized against the corresponding $\beta$-actin mRNA levels and then expressed as the relative change from the control $\pm \mathrm{SD}$. The expected sizes of amplicons were confirmed by gel electrophoreses. The sequences of the genes studied were obtained 
Table I. Amplicon size and primer sequences of genes.

\begin{tabular}{lcc}
\hline Gene & Primer sequence & Amplicon size (bp) \\
\hline$\beta$-actin & F: 5'-AAGGACCTGTATGCCAACACA-3' & 152 \\
& R: 5'-ATCCACACAGAATACTTGCGTT-3' & 199 \\
Cav1.2 & F: 5'-GACGCTATGGGCTATGAGTTAC-3' & \\
& R: 5'-AGTCCAGGTAGCCCTTTAGGT-3' & \\
\hline
\end{tabular}

Table II. ECG data of adult and aged dogs (mean \pm SD).

\begin{tabular}{lccccc}
\hline Group & P wave (msec) & PWD interval (msec) & PR interval (msec) & QRS interval (msec) & QT interval (msec) \\
\hline Adult & $66.1 \pm 6.4$ & $19.1 \pm 4.1$ & $123.9 \pm 7.2$ & $63.1 \pm 4.3$ & $248.9 \pm 11.7$ \\
Aged & $75.9 \pm 5.3^{\mathrm{a}}$ & $26.7 \pm 3.1^{\mathrm{a}}$ & $130.0 \pm 7.7$ & $64.7 \pm 5.4$ & $246.5 \pm 17.3$ \\
\hline
\end{tabular}

${ }^{a} \mathrm{P}<0.05$ vs. adult canines. ECG, electrocardiogram; PR interval, from starting point of $\mathrm{P}$ wave to the starting point of QRS wave in electrocardiogram; QRS interval, rom starting point of QRS wave to the ending point of QRS wave in electrocardiogram; QT interval, from starting point of QRS wave to the ending point of $\mathrm{T}$ wave in electrocardiogram.

Table III. Action potential characteristics recorded from adult and aged canine atria at a cycle length of $2000 \mathrm{msec}(\mathrm{mean} \pm \mathrm{SD})$.

\begin{tabular}{lcccc}
\hline Group & MDP $(\mathrm{mv})$ & APA $(\mathrm{mv})$ & Plateau $(\mathrm{mv})$ & $\mathrm{APD}_{90}(\mathrm{msec})$ \\
\hline Adult & $-78.8 \pm 0.8$ & $109.8 \pm 1.4$ & $-6.4 \pm 1.1$ & $320.0 \pm 7.9$ \\
Aged & $-79.2 \pm 1.4$ & $110.5 \pm 4.9$ & $-9.5 \pm 1.7$ & $340.5 \pm 10.1^{\mathrm{a}}$ \\
\hline
\end{tabular}

${ }^{\mathrm{a}} \mathrm{P}<0.05$ vs. adult canines. MDP, maximum diastolic potential; $\mathrm{APA}$, action potential amplitude; $\mathrm{APD}_{90}$, action potential duration to $90 \%$ repolarization.

from GenBank and the primers were designed using PRIMER 5.0 software (Applied Biosystems, Carlsbad, CA, USA). The amplicon size and primer sequences for the genes are shown in Table I.

Assessment of Cav1.2 protein expression. For western blotting, $50 \mu \mathrm{g}$ protein was solubilized for $5 \mathrm{~min}$ at $95^{\circ} \mathrm{C}$ in one volume of loading buffer, loaded onto $10 \%$ SDS-PAGE gels and then transferred to nitrocellulose membranes (Bio-Rad, Hercules, CA, USA). The membranes were blocked with $5 \%$ nonfat dry milk in PBST (containing $0.05 \%$ Tween 20 ), incubated overnight at $4^{\circ} \mathrm{C}$ with the primary antibody (Cav1.2, 1:2,000; goat IgG, polyclone; Santa Cruz Biotechnology Inc., Santa Cruz, CA, USA), washed in PBST, incubated with horseradish peroxidase-conjugated secondary antibody and revealed using Immun-Star HRP Substrate (Bio-Rad). For normalization of gel loading, the same western blots were reprobed with anti- $\beta$-actin (dilution, 1:200; Santa Cruz Biotechnology Inc.). The densities of the bands on the western blots were quantified using an automatic gel imaging and analysis system (Bio-Rad).

Statistical analysis. Statistical analysis was performed using SPSS 18.0 software (SPSS, Inc., Chicago, IL, USA). All values are expressed as the mean $\pm \mathrm{SD}$. Comparisons between the

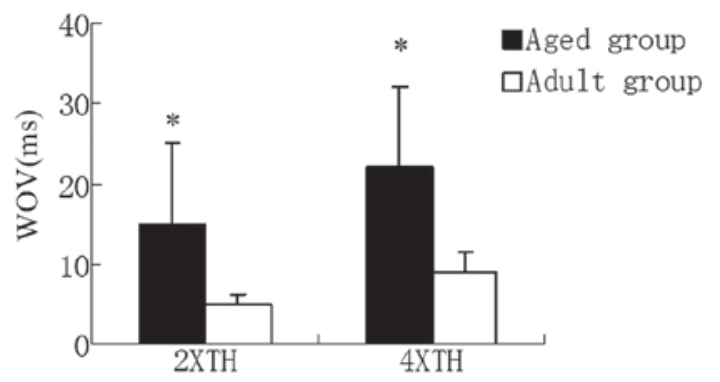

Figure 1. Determination of the window of vulnerability (WOV) for atrial fibrillation (AF) when programmed stimulation was performed at the RAA in adult and aged dogs. ${ }^{*} \mathrm{P}<0.05$ vs. adult dogs. RAA, right atrial appendage; TH, threshold.

two groups were made using the Student's $\mathrm{t}$ test. $\mathrm{P}<0.05$ was considered to indicate a statistically significant difference.

\section{Results}

ECG data. ECG data concerning the sinus rhythm for the adult and aged groups are shown in Table II. The ECGs of the aged group exhibited prolonged $\mathrm{P}$ wave durations and increased $\mathrm{P}$ wave dispersion (PWD) compared with those of the adult 
Table IV. Electrophysiological characteristics of the L-type calcium current $\left(\mathrm{I}_{\mathrm{Ca.L}}\right)$ in adult and aged canine $\mathrm{LA}$ cells (mean $\left.\pm \mathrm{SD}\right)$.

\begin{tabular}{|c|c|c|c|c|c|c|c|}
\hline \multirow[b]{2}{*}{ Group } & \multirow[b]{2}{*}{$\mathrm{n}$} & \multirow{2}{*}{$\begin{array}{l}\mathrm{I}_{\mathrm{Ca} . \mathrm{L}} \text { density } \\
(\mathrm{pA} / \mathrm{pF})\end{array}$} & \multicolumn{2}{|c|}{ Steady-state activation } & \multicolumn{2}{|c|}{ Steady-state inactivation } & \multirow{2}{*}{$\begin{array}{l}\text { Monoexponential recovery } \\
\text { time constants }(\mathrm{msec})\end{array}$} \\
\hline & & & $\mathrm{V}_{0.5}(\mathrm{mV})$ & $\mathrm{K}(\mathrm{mV})$ & $\mathrm{V}_{0.5}(\mathrm{mV})$ & $\mathrm{K}(\mathrm{mV})$ & \\
\hline Adult & 14 & $-8.1 \pm 0.5$ & $-7.1 \pm 1.5$ & $5.7 \pm 0.4$ & $-23.1 \pm 2.1$ & $6.2 \pm 0.3$ & $51.9 \pm 3.3$ \\
\hline Aged & 16 & $-14.1 \pm 0.8^{a}$ & $-6.7 \pm 2.8$ & $5.5 \pm 0.5$ & $-22.9 \pm 3.3$ & $6.4 \pm 0.5$ & $53.1 \pm 3.1$ \\
\hline
\end{tabular}

${ }^{\text {a }}<<0.05$ vs. adult. $\mathrm{n}$, cell number; $\mathrm{V}_{0.5}$, half-activation or -inactivation voltage; $\mathrm{K}$, slope factor; $\mathrm{pA} / \mathrm{pF}$, current density.
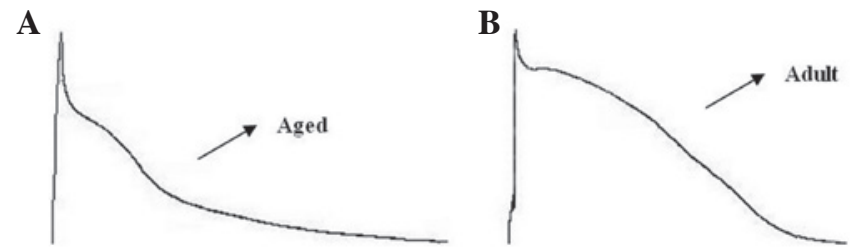

Figure 2. Action potential (AP) recording from the left atrial (LA) cells of (A) aged and (B) adult dogs.

group. Other variables were not observed to differ between the two groups.

Induced $A F$. As shown in Fig. 1, programmed electrical stimulation at the RAA in the aged group induced a larger WOV $(15 \pm 7.5 \mathrm{~ms})$ compared with that of the adult group $(5 \pm 2.5 \mathrm{msec})$ during $2 \mathrm{X}$ TH. A similar result was observed during $4 \mathrm{X} \mathrm{TH}$ (aged group, $22 \pm 12 \mathrm{msec}$ vs. adult group, $9 \pm 4.5 \mathrm{msec}$ ).

AP characteristics. LA cells from aged atria exhibited longer APDs and lower plateau potentials compared with those from adult atria. Representative AP recordings from the adult and aged groups are shown in Fig. 2. AP characteristics, at a cycle length of 2,000 msec, are shown in Table III. While there were no significant differences in the maximum diastolic potential (MDP) or action potential amplitude (APA), action potential duration to $90 \%$ repolarization $\left(\mathrm{APD}_{90}\right)$ was longer in the aged dogs, indicating that the slope of phase 3 repolarization was more gradual in the aged than in the adult cells.

$I_{C a . L}$. Typical $\mathrm{I}_{\mathrm{Ca} . \mathrm{L}}$ recordings from LA cells of the adult and aged dogs are shown in Fig. 3. Aged LA cells had lower peak $\mathrm{I}_{\text {Ca.L }}$ densities than adult LA cells $(-8.1 \pm 0.5$ vs. $-14.1 \pm 0.8$, respectively, $\mathrm{P}<0.05$; measured at $+10 \mathrm{mV})$. Activation voltage dependence was assessed from depolarization-induced currents and the driving force was corrected with driving force corrected by membrane potential-reversal potential, where reversal potential is the voltage axis intercept of the ascending limb of the current-voltage relation. There were no significant differences in half-activation voltage or slope factor between the two groups (Table IV). Inactivation was assessed with 1-sec prepulses of $-60,-50,-40,-30,-20,-10$, $0,10,20,30$ and $40 \mathrm{mV}$, followed by $250-\mathrm{msec}$ test pulses to $+10 \mathrm{mV}$. Furthermore, the current reduction in the aged cells was not accompanied by a significant change in the refractory period (Table IV).
A

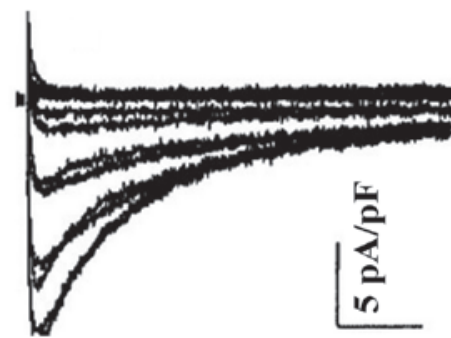

B
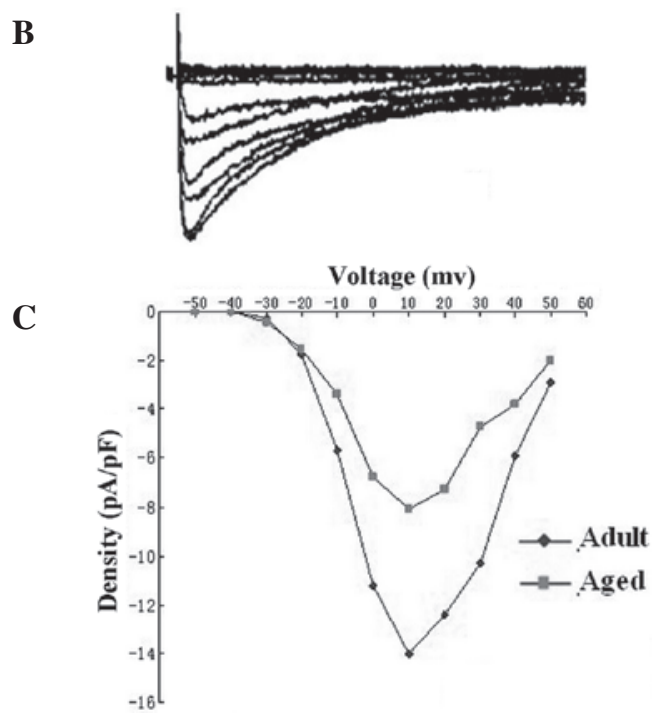

Figure 3. Typical L-type calcium current $\left(\mathrm{I}_{\mathrm{ca}-\mathrm{L}}\right)$ recordings obtained from left atrial (LA) myocytes in adult and aged dogs. (A) Adult LA cell; (B) aged LA cell; (C) mean $\mathrm{I}_{\text {ca-L }}$ density-voltage relationship in adult (cells, $\mathrm{n}=11$; hearts, $\mathrm{n}=7$ ) and aged (cells, $\mathrm{n}=13$; hearts, $\mathrm{n}=10$ ) LA cells.

Cav1.2 gene expression in LA cells. To study Cav1.2 expression in LA cells, Cav1.2 mRNA levels were analyzed using qPCR. The specificity of the amplified PCR product was verified using agarose gel electrophoresis and non-specific DNA fragments were not detected (Fig. 4A). Cav1.2 mRNA levels were decreased in the aged group compared with those in the adult group ( $\mathrm{P}<0.05$, Fig. 4B).

Cav1.2 protein expression in LA cells. To confirm the $\mathrm{qPCR}$ results, western blotting was performed with Cav1.2 antibodies. Fig. 5A presents the bands from a gel on which the Cav1.2 protein levels from LA cells were studied. The $\beta$-actin bands were used to confirm that the loading was equal. Densitometric data demonstrated that the Cav1.2 protein levels were significantly lower in the aged group compared with those in the adult group $(\mathrm{P}<0.05$, Fig. $5 \mathrm{~B})$. 
A

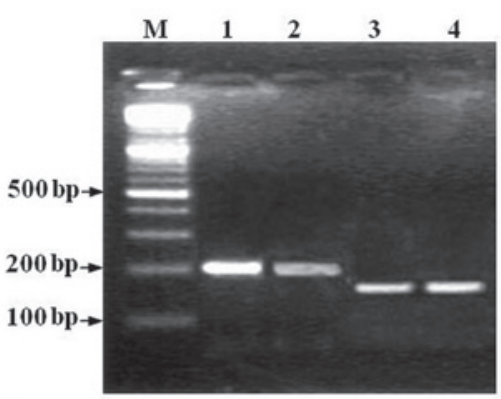

B

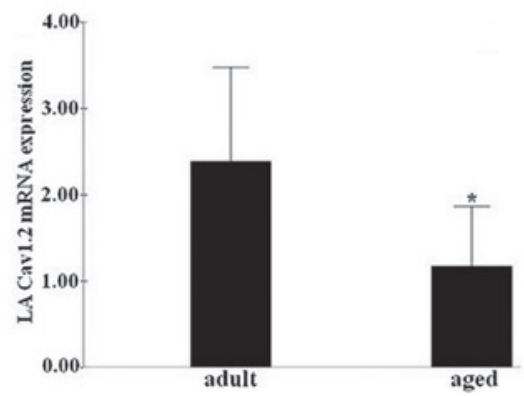

Figure 4. Decline in Cav1.2 mRNA expression with increasing age in the left atrial (LA) cells of canines. (A) Quantitative PCR (qPCR) products for Cav1.2 and $\beta$-actin. M, DNA marker; lane 1, Cav1.2 (adult); lane 2, Cav1.2 (aged); lane 3, $\beta$-actin (adult); lane $4, \beta$-actin (aged). (B) Relative Cav1.2 mRNA expression levels. ${ }^{*} \mathrm{P}<0.05$ vs. adult canines.

\section{Discussion}

In the present study, the susceptibility to AF was greater in the aged dog group than in the adult group. We hypothesized that certain electrophysiological changes in the atria were responsible for this difference. We demonstrated that certain characteristics of the APs in LA cells change with increasing age. The most marked alteration was a significant lowering of the plateau potential in aged LA cells. Previous studies have shown that negative plateau potentials have a lower driving force in the conduction of early premature beats (12). Therefore, our results imply that alterations in the APs of aged atrial cells are likely to lead to a decreased conduction of premature beats in aged atria. The slow conduction of early premature impulses may further facilitate the onset of AF. The currents that determine the plateau level of APs in the atrium are $\mathrm{I}_{\mathrm{Kur}}, \mathrm{I}_{\mathrm{to}}$ and $\mathrm{I}_{\mathrm{Ca.L}}$ (13). Therefore, a reduction in the depolarizing current $\left(\mathrm{I}_{\mathrm{Ca} . \mathrm{L}}\right)$ or an increase in the repolarizing currents ( $\mathrm{I}_{\mathrm{Kur}}$ and/or $\mathrm{I}_{\mathrm{to}}$ ) may lead to a lower AP plateau (14). Moreover, the $\mathrm{APD}_{90}$ value in LA cells was prolonged with age; this may be the result of age-induced changes in the delayed rectifier potassium current $\left(\mathrm{I}_{\mathrm{K}}\right)$ or may simply be a consequence of the low AP plateau in aged canines.

In addition to age-associated changes in the $\mathrm{I}_{\mathrm{Ca} . \mathrm{L}}$ of LA cells, previous studies have also reported that $\mathrm{I}_{\mathrm{Ca} . \mathrm{L}}$ is reduced in the RA cells of aged canines compared with those of adult canines. However, no previous studies have reported on the effects of age on LA cell $\mathrm{I}_{\mathrm{Ca.L}}$. In the current study, we showed that there was a significant reduction in the peak $\mathrm{I}_{\mathrm{Ca.L}}$ in aged canine LA cells compared with that in adult canine LA cells. The current reduction in aged cells was not accompanied by a significant change in $\mathrm{Ca}^{2+}$ channel availability or recovery from inactivation. These results suggest that a reduction in the
A

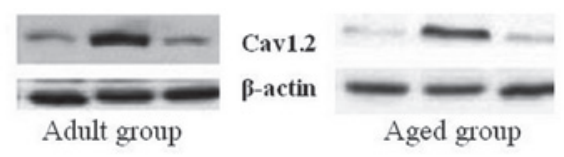

B

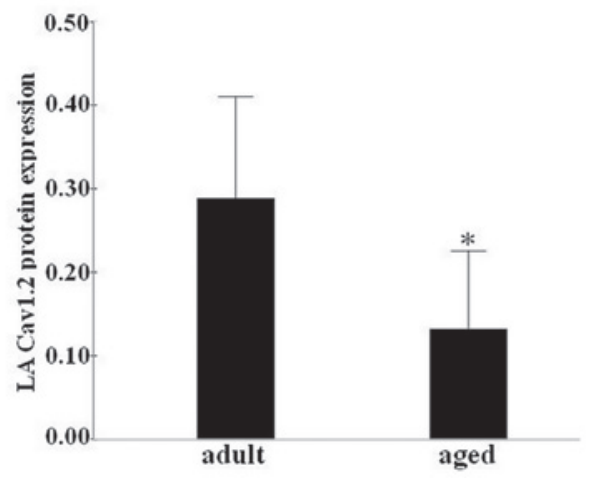

Figure 5. Decline in Cav1.2 protein expression levels with increasing age in the left atrial (LA) cells of dogs. (A) Western blotting bands for Cav1.2 and $\beta$-actin. (B) Relative Cav1.2 protein expression levels. " $\mathrm{P}<0.05$ vs. adult dogs.

$\mathrm{I}_{\text {Ca.L }}$ is a major mechanism underlying the low AP plateau in aged canine LA cells.

The PWD was significantly longer in the aged dogs than in the adult canines. This may be a result of the degree of age-associated reduction in the conduction of the atria (15). Age-related changes in the content and distribution of connective tissue in the atria reduce the degree of cellular coupling and lead to discontinuous propagation, thus slowing conduction (16). Under normal conditions, sufficient depolarizing current is transferred across such discontinuities to maintain normal propagation. However, when the depolarizing current is reduced, conduction slows (17). The driving force of the discontinuous conduction is determined by the plateau potential, and the $\mathrm{I}_{\mathrm{C} . \mathrm{L}}$ is important in the maintenance of conduction $(18,19)$. Therefore, the present results imply that the reductions in $\mathrm{I}_{\mathrm{CaL}}$ and AP plateau potential in aged LA cells may lead to the occurrence of discontinuous conduction. These findings may constitute a mechanism via which aged atria become more susceptible to AF.

In cardiac myocytes, $\mathrm{Ca}^{2+}$ currents through L-type $\mathrm{Ca}^{2+}$ channels are the main mechanism for $\mathrm{Ca}^{2+}$ influx from the extracellular space into the cytoplasm (20). Cardiac L-type $\mathrm{Ca}^{2+}$ channels are composed of four polypeptide subunits $(\alpha 1, \beta, \alpha 2$ and $\delta$ ) (21). The $\alpha 1$ subunit is the most important polypeptide of the $\mathrm{Ca}^{2+}$ channel-forming proteins; it forms the channel pore for ion flow and is responsible for voltage-dependent $\mathrm{Ca}^{2+}$ channel opening and channel selectivity for $\mathrm{Ca}^{2+}$ ions $(22,23)$. To date, at least 10 different $\alpha 1$ subunit genes have been identified, but only the a1C (Cav1.2) isoform is expressed at high levels in cardiac muscle (24). The current study demonstrated that Cav1.2 mRNA and protein expression levels in LA cells were significantly lower in the aged group compared with those in the adult group. This may be the main cause of the reduction in $\mathrm{I}_{\mathrm{Ca} . \mathrm{L}}$ in aged canines. Jones et al (25) obtained similar findings, demonstrating that within the sinoatrial (SA) node, an age-related decline in the expression levels of the Cav1.2 protein caused the suppression of AP formation and propagation, leading to failure of the SA node as a pacemaker. 
Therefore, atria Cav1.2 protein levels may decrease with age. However, research has been limited to studies using Cav1.2 protein from only one region of the left atrium and SA node (one region of RA). The mechanisms underlying these changes are unknown. We hypothesized that aging may result in the progressive deterioration of physiological functions and metabolic processes, which alters the density and distribution of ion channels.

Previous studies have attached particular importance to the left atrium in the initiation and maintenance of $\operatorname{AF}(26,27)$. The present study demonstrated that there were age-associated changes in the electrophysiological properties and ion channels of the LA myocardium. A lower AP plateau potential and decreased $\mathrm{I}_{\mathrm{CaL}}$ in the LA cells of aged canines may contribute to the slow and discontinuous conduction in the left atrium. These changes increase the susceptibility of aged atria to AF. Furthermore, the decreased expression of Cav1.2 with age may be the cause of the reduction in $\mathrm{I}_{\mathrm{Ca} . \mathrm{L}}$ with increasing age. However, further studies of the mechanisms of alteration in Cav1.2 expression are required.

Although the present study demonstrated age-associated electrophysiological and molecular changes in the LA cells of aged canines, the extent to which these effects are clinically applicable remains to be determined.

\section{Acknowledgements}

This study was supported by the National Natural Science Foundation of China (no. 308660299), the Natural Science Foundation of the Xinjiang Uygur Autonomous Region (no. 200821143) and the Doctoral Fund of the Ministry of Education (no. 200807600004).

\section{References}

1. Chen LY and Shen WK: Epidemiology of atrial fibrillation: a current perspective. Heart Rhythm 4 (Suppl): S1-S6, 2007.

2. Go AS: The epidemiology of atrial fibrillation in elderly persons: the tip of the iceberg. Am J Geriatr Cardiol 14: 56-61, 2005.

3. Murgatroyd FD and Camm AJ: Atrial arrhythmias. Lancet 341: 1317-1322, 1993.

4. Allessie MA, Boyden PA, Camm AJ, et al: Pathophysiology and prevention of atrial fibrillation. Circulation 103: 769-777, 2001.

5. Corradi D, Callegari S, Maestri R, Benussi S and Alfieri O: Structural remodeling in atrial fibrillation. Nat Clin Pract Cardiovasc Med 5: 782-796, 2008.

6. Anyukhovsky EP, Sosunov EA, Chandra P, et al: Age-associated changes in electrophysiologic remodeling: a potential contributor to initiation of atrial fibrillation. Cardiovasc Res 66: 353-363, 2005.

7. Dun W and Boyden PA: Aged atria: electrical remodeling conducive to atrial fibrillation. J Interv Card Electrophysiol 25: 9-18, 2009.

8. Nattel S: Atrial electrophysiological remodeling caused by rapid atrial activation: underlying mechanisms and clinical relevance to atrial fibrillation. Cardiovasc Res 42: 298-308, 1999.
9. Dun W, Yagi T, Rosen MR and Boyden PA: Calcium and potassium currents in cells from adult and aged canine right atria. Cardiovasc Res 58: 526-534, 2003.

10. Tipparaju SM, Kumar R, Wang Y, Joyner RW and Wagner MB: Developmental differences in L-type calcium current of human atrial myocytes. Am J Physiol Heart Circ Physiol 286: H1963-H1969, 2004.

11. Bayne K: Revised Guide for the Care and Use of Laboratory Animals available. American Physiological Society. Physiologist 39: 199, 208-211, 1996.

12. Sugiura H and Joyner RW: Action potential conduction between guinea pig ventricular cells can be modulated by calcium current. Am J Physiol 263: H1591-H1604, 1992.

13. Yue L, Feng J, Li GR and Nattel S: Transient outward and delayed rectifier currents in canine atrium: properties and role of isolation methods. Am J Physiol 270: H2157-H2168, 1996.

14. Anyukhovsky EP, Sosunov EA, Plotnikov A, et al: Cellular electrophysiologic properties of old canine atria provide a substrate for arrhythmogenesis. Cardiovasc Res 54: 462-469, 2002.

15. Podrid PJ: Atrial fibrillation in the elderly. Cardiol Clin 17: 173-188, 1999.

16. Spach MS and Dolber PC: Relating extracellular potentials and their derivatives to anisotropic propagation at a microscopic level in human cardiac muscle. Evidence for electrical uncoupling of side-to-side fiber connections with increasing age. Circ Res 58 : 356-371, 1986.

17. Spach MS, Miller WT, Dolber PC, Kootsey JM, Sommer JR and Mosher CE Jr: The functional role of structural complexities in the propagation of depolarization in the atrium of the dog. Cardiac conduction disturbances due to discontinuities of effective axial resistivity. Circ Res 50: 175-191, 1982.

18. Shaw RM and Rudy Y: Ionic mechanisms of propagation in cardiac tissue. Roles of the sodium and L-type calcium currents during reduced excitability and decreased gap junction coupling. Circ Res 81: 727-741, 1997.

19. Rohr S and Kucera JP: Involvement of the calcium inward current in cardiac impulse propagation: induction of unidirectional conduction block by nifedipine and reversal by Bay K 8644 . Biophys J 72: 754-766, 1997.

20. Richard S, Perrier E, Fauconnier J, et al: ' $\mathrm{Ca}^{2+}$-induced $\mathrm{Ca}^{2+}$ entry' or how the L-type $\mathrm{Ca}^{2+}$ channel remodels its own signalling pathway in cardiac cells. Prog Biophys Mol Biol 90: $118-135,2006$

21. Yamakage M and Namiki A: Calcium channels - basic aspects of their structure, function and gene encoding; anesthetic action on the channels - a review. Can J Anaesth 49: 151-164, 2002.

22. Wang MC, Dolphin A and Kitmitto A: L-type voltage-gated calcium channels: understanding function through structure. FEBS Lett 564: 245-250, 2004

23. Bodi I, Mikala G, Koch SE, Akhter SA and Schwartz A: The L-type calcium channel in the heart: the beat goes on. J Clin Invest 115: 3306-3317, 2005.

24. Treinys $\mathrm{R}$ and Jurevicius J: L-type $\mathrm{Ca}^{2+}$ channels in the heart: structure and regulation. Medicina (Kaunas) 44: 491-499, 2008.

25. Jones SA, Boyett MR and Lancaster MK: Declining into failure: the age-dependent loss of the L-type calcium channel within the sinoatrial node. Circulation 115: 1183-1190, 2007.

26. Tada H, Kurosaki K, Ito S, et al: Left atrial and pulmonary vein ostial ablation as a new treatment for curing persistent atrial fibrillation. Circ J 69: 1057-1063, 2005.

27. Roithinger FX, Steiner PR, Goseki Y, Sparks PB and Lesh MD: Electrophysiologic effects of selective right versus left atrial linear lesions in a canine model of chronic atrial fibrillation. J Cardiovasc Electrophysiol 10: 1564-1574, 1999. 